\title{
循環器内科による頸動脈ステントの初期成績
}

\section{伊芠 裕二}

〔日内会誌 $101 ： 3274 ３ 276 ， 2012 〕$

Key words Carotid artery stenting, carotid stenosis, stroke

\section{研究の要旨}

背景：頸動脈ステント(CAS) は脳神経外科, 血管外科, 放射線科, 循環器内科医などにより 施行されているが, 日本においては現在脳神経 外科による施行例が多い. しかし，CASは心筋 梗塞, 徐脈, 低血圧などの心血管合併症が多く, また手技的にも心血管インターベンションに近 いことから，世界的には循環器内科医により施 行される方が多い. 日本における循環器内科医 によるCASの成績は今までに一つも報告されて いない.

目的：日本において循環器内科医による頸動 脈ステント (CAS) の成績を明らかにすること.

研究デザイン：後ろ向きレジストリー研究

一次エンドポイント：30日目までの主要合併 症 (MAE : 総死亡, 脳卒中, 心筋梗塞)

方法 : 2008 年 4 月から 2010 年までにその時点 で唯一の保険承認品であるPreciseステントとAngioguardフィルターを用い循環器内科医により施 行されたCASの成績を後ろ向きに登録した.

結果：2008 年から 2010 年の間に施行された CASを 55 施設より 704 例の登録があった. 平均
年齢 $74 \pm 8$ 歳, $62 \%$ は非症候性であった. $23 \%$ の症例には対側頸動脈に有意狭窄または閉塞を 認めた. Angioguardフィルターワイヤーが使用 され，99.6\%に留置成功した. Preciseステント は全例に留置成功した. 30 日目の成績は, 死亡 率 $0.3 \%$, 脳卒中 $3.4 \%$, 心筋梗塞 $0 \%$ であり, 一 次エンドポイントである 30 日目のMAEは 3.7\% であった，死亡＋脳卒中率に関しては, 症候性 で $5.5 \%$, 非症候性で $2.7 \%$ であった。

考察：海外のガイドラインにおいては, 死亡 + 脳卒中率を症候性例で $6 \%$ 未満, 非症候性で $3 \%$ 未満を達成するべきと言われている11. 逆に この数值を達成できない術者は, CASもCEA (頸動脈内膜摘除術)も行うべきではないとされ ている. 同じ時期に行われた日本における市販 後調査においては $8 \%, 4 \%$ とガイドラインの目 標值を達成できなかった。すなわち, 日本にお いてCASは施行するべきではないということを 示唆する大問題の数值が報告された. 市販後調 査の登録例の 9 割は脳神経外科によるものであ り, ステント留置手技に精通した循環器内科に よる成績を明らかにするのは必須のことであっ た. CASCARD研究では症候性 5.5\%, 非症候性 $2.7 \%$ とガイドラインの目標值を達成できた. そ 
の理由の考察に関して様々な意見はあるが, 少 なくとも日本において循環器内科医が施行する CASは許容範囲であり, 日本においてCASは継 続するべきであると考えられた.

\section{研究の特徵と新規事項}

脳梗塞の 3 大原因として, 心房細動, 頸動脈 狭窄，高血圧などによるラクナ梗塞がある．頸 動脈狭窄症によるアテローム血栓塞栓症は脳梗 塞全体の約 2 割から 3 割を占めると考えられ非 常に重要である. その予防として, 内科治療が 第一選択であり重要であるが, 1990 年代にCEA が症候性かつ高度狭窄例においては内科治療よ りも成績が良いと報告された ${ }^{22}$. その後, インター ベンション治療の発展によりCASが報告された. CEA とCASの比較試験の結果は, 2004 年のSAPPHIRE試験において ${ }^{3)}$, CEAハイリスク例に対し てはCASのNon-inferiorityが示された.ところが, その後CEAハイリスク以外にも適応を考えた時 の比較試験では結果が紆余曲折し, CASがCEA に劣るという結果がいくつも報告された。 これ らは試験のデザインが未熟であることが問題で あり, 2010 年に良くデザインされたCREST研究 が報告され ${ }^{4)}$, ようやくCASとCEAの同等性が示 された。

日本におけるCASの適応は 2008 年に世界で最 後に承認されたが，この時には日本においては 治験がなされず, 2004 年のSAPPHIRE研究を元 にした海外データで承認がおりたため, 市販後 調查において海外データと同等であることを確 認することが必須であった。

ところが, 市販後調查においてはガイドライ ンにて示されてきたCASでもCEAでも脳梗塞+ 死亡率は症候性 6\% 以下, 非症候性 3\% 以下の ゴールドスタンダード1)を達成することができな かった，日本における治験がないことなどに対 する疑問も提示された. しかしながら, 海外に
おいて良好なデータが示された同じデバイスで あるのに，なぜ日本における市販後調査でより 悪いデータが出てしまったのかは十分に考察し なければ, 日本におけるCASの適応が消滅して しまうことになるため注意を要する. 市販後調 查では日本の施行実態を示し, 9 割が脳神経外科 による登録であった，そこでまず循環器内科医 によるCASの初期成績を示すことは日本におけ るCAS治療そのものを継続するか否かの重大な テーマであった。 よって後ろ向きに初期デー夕 を集めたのが本研究である.CASのデータは世 界的にはほぼ安定して出揃ってきている. した がって，世界的なノイエスとは言えないが，日 本において全く術者がいないといころから，教 育プログラムを組み, 症例見学に出向き, また 初めて実施する施設に指導医が出向いて指導を おこなうというプロクター制度など学会主導で 大掛かりな準備を日本のCASの立ち上げで行っ た.しかし，市販後調查の結果は，諸外国にお ける標準的なレベルを下回る結果であり，ガイ ドラインに従えば日本ではCASを行うべきでは ないという結論になる. CASの立ち上げを企画 した一人として大きな危機に直面していた，日 本においてCASを続けるべきなのか, 続けるこ とで国民の健康に繋がるのかというのがCASCARD研究の一つの大きなテーマであった.

\section{研究の弱点とその対応処置}

レトロスペクティブなデザインが最大の弱点 と言える. したがって, 脳梗塞のイベントに関 しては, カルテ上の記載に頼るのみで, 神経専 門医による所見は取られていない.

\section{研究遂行時の問題点}

上記の理由により，素早くデー夕を集める必 要があった。各施設とは, 研究主任者 (PI) 施 
設である東海大学と契約を結び協力金を支払っ た. 早いデータの登録のため, コーディネーター からこまめに連絡をとり, デー夕を提出して頂 いた。

\section{今後の展望}

高齢化を迎えた日本人において頸動脈狭窄の 頻度はますます増加すると考えられる.そして， 脳梗塞がQOLを低下させる重大な疾患であるこ とを考えると有効かつ的確な予防法としてのCAS は重要な手技である.

CASのデバイスも承認品が増加している. 前 向きな各デバイスのデータに関して比較検討が 必要である。 また, 循環器内科以外にも脳神経 外科, 神経内科, 放射線科, 血管外科などにお いてもCASは施行されているため術者間比較の デー夕も必要である。そして, 未だに最大の問 題としてはCASとCEAの比較試験である. 日本 においてもよくデザインされた比較試験は今後 調査されなければならない。内科治療の進歩は 著しくスタチンや抗血小板剤により内科治療の 脳梗塞予防率は明らかに改善している. NASCET 試験という最初のCEAと内科的治療の比較の時 代は, スタチンもクロピドグレルもない時代の ものであり, 最新の内科治療とCASもしくはCEA の比較も必要である。手技に関してはEmbolic protection deviceは現在必須と考えられている が, 真に無作為試験で証明されたわけでもない. また, フィルターなどの遠位保護型と近位保護 型の成績比較も重要である.CASにおけるイメー ジングの重要性は明らかであるが, MRIのガイ

ド，血管内超音波ガイドなど，これらの手技の
有効性もまだ明らかではない，頸動脈狭窄治療 には明らかになっていない領域が多く, 発展性 のある領域と考えられる. CASCARDはPrecise ステントとAngioguardフィルターを用いた日本 における最初のまとまったCASデータであり， 今後出てくる日本のCASの成績とは重要な比較 対象になると思われる.

著者のCOI (conflicts of interest) 開示 : 伊茫裕二 ; 特許使 用料 (テルモ), 研究費・助成金 (朝日インテック, エーザイ, カネカメディックス, サノフィ・アベンティス, 第一三共, テルモ, 日本ライフライン), 旅費・贈答品(アボットバスキュー ラー, サノフィ・アベンティス, テルモ)

\section{文献}

1) Brott TG, et al:2011 ASA/ACCF/AHA/AANN/AANS/ $\mathrm{ACR} / \mathrm{ASNR} / \mathrm{CNS} / \mathrm{SAIP} / \mathrm{SCAI} / \mathrm{SIR} / \mathrm{SNIS} / \mathrm{SVM} / \mathrm{SVS}$ guideline on the management of patients with extracranial carotid and vertebral artery disease : executive summary. A report of the American College of Cardiology Foundation/American Heart Association Task Force on Practice Guidelines, and the American Stroke Association, American Association of Neuroscience Nurses, American Association of Neurological Surgeons, American College of Radiology, American Society of Neuroradiology, Congress of Neurological Surgeons, Society of Atherosclerosis Imaging and Prevention, Society for Cardiovascular Angiography and Interventions, Society of Interventional Radiology, Society of NeuroInterventional Surgery, Society for Vascular Medicine, and Society for Vascular Surgery. Circulation 124 : 489-532, 2011.

2) Beneficial effect of carotid endarterectomy in symptomatic patients with high-grade carotid stenosis. North American Symptomatic Carotid Endarterectomy Trial Collaborators. N Engl J Med 325 : 445-453, 1991.

3) Yadav JS, et al: Protected carotid-artery stenting versus endarterectomy in high-risk patients. N Engl J Med 351 : 1493-1501, 2004.

4) Brott TG, et al: Stenting versus endarterectomy for treatment of carotid-artery stenosis. N Engl J Med 363: 11-23, 2010. 